\title{
Observed travel times for Multiply-reflected ScS waves from a deep-focus earthquake
}

\author{
A. F. Espinosa $(*)$
}

Ricevuto il 26 Agosto 1960

\begin{abstract}
Summary. - The deep-foeus Argentinean earthquake of December 8 1962, generated multiply reftected SeS phases which were recorded very clearly at stations of the $I G Y$ and the $U S C$ C GS standardized worldwide networks and at Canadian stations. The data gathered from this eartl. quake for the multiply-reflected ScS and sSeS were used to construct the travel times and to extend them to shorter epicentral distances. These new data brought to liglıt an error in published travel times for the $2(S c S)$ phase.
\end{abstract}

Riasscito. - Il terremolo profondo avventuto in Argentina l's Di. cembre 1962 , ha originato onle scs riflesse più volte, che sono state registrate molto chiaraneste dalle stazioni sisuiche dollit rete mondiale standard rell'IGY e dell'USC\&GS e datle starioni camalusi.

1 dati raccolti mediante lo studio di questo terremoto per le onde Schs e sScS, somo stati usati per costruire la curva dei tempi di tratgitto ed estesi a distanze epicentrali più brevi.

Questi nuovi dati, inoltre, hatmo nesso in luce un errore relativo ai tempi di tragitto gial pubblicati per le onde $2\left(S^{\prime} S S^{+}\right)$.

\section{INTRODECION}

Multiply-reflerted sest and their surface inliges from the December 8, 1962, deep-focus earthquake in Argentina were unusually well recorled by long-period seismogratphs at stations of the $I G Y$ and the $U S C d$ GS standardized network, and at Canadian stations. This investigation describes a study made on the identifieation of the multiply-reflected

$\left.{ }^{*}\right)$ Environmental Science Sorvices Admintstration, U.S. Coast and Geodetic Survey. Rockville, Maryland. 


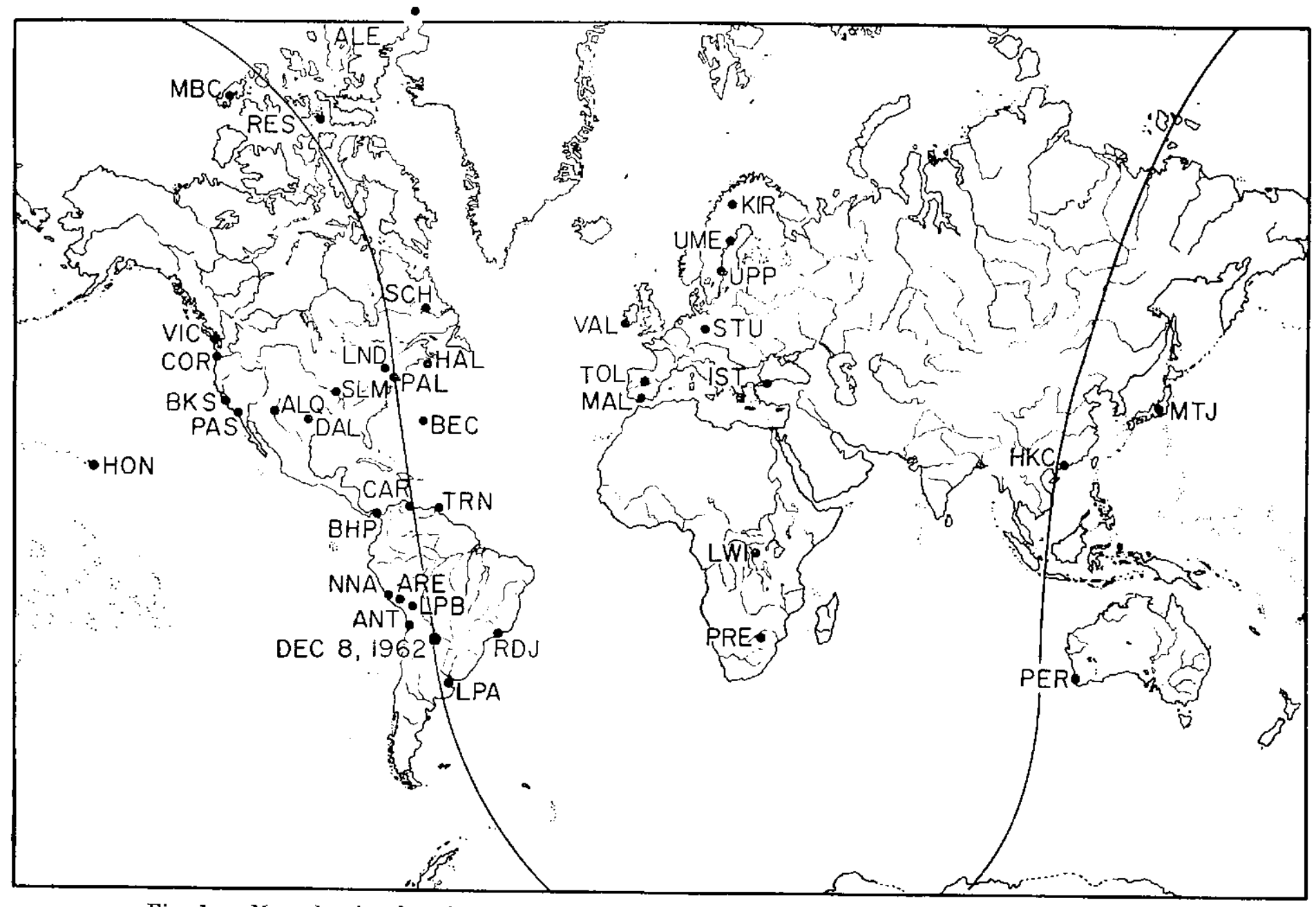

芯

Fig. 1. - Map showing location of epicester, stations, and a great circle path through Palisades. 
phises, and the constraction of their traveltinuss as recorded on longperiod instruments. The observitions of the trarel-times of the $2(s \mathrm{r} S)$ at shorter epicentral distinces have permitted the extension of the traveltime curve for this phase down to an epresentral distanes of $7^{\circ}$. Pre-

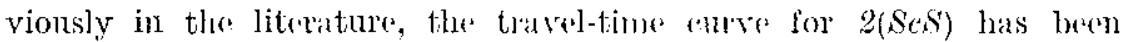
given for an epicentral distanese grate than $90 \%$. The $n(S C S)$ family of phases has been identified without any doubt by the presence of the n(sSeS) phases on the recordings. Trantifintion of phases traveling in the major cijele path is shown. In the process of plotting the observed travel times of the $2(S t S)$ platsen, an wror in the published traveltime eurve for this phase has beren found, for a depth of focus of $600 \mathrm{~km}$.

\section{INTERPRETATION OF THE DATA}

The epicenter, origin time, and depth of focus for the December 8 , 1962, eathrualie wore Iocited by using Bolt's (1960) program for the $7090 I B A I$ computer. One humber fifty raclings of impulsive $P$ phases, $14 p P$ and 10 PKP rearlings, whe used in the relocation. The pertinent data are listed in Table $\mathrm{I}$.

Table I

\begin{tabular}{|c|c|c|c|c|c|}
\hline \multicolumn{2}{|c|}{ Epicenter } & $\begin{array}{c}\text { Origin Time } \\
\left(G N^{T} T\right)\end{array}$ & Depth & Magnitude & \\
\hline $25.8^{\circ} \quad S$ & $63.4^{\circ} \quad W$ & $21 \quad 2722.2$ & 620 & $7 P A S$ & \multirow[t]{2}{*}{$U S C \& G S$} \\
\hline $25.78^{\circ} S$ & $62.15^{\circ} \mathrm{W}$ & $21 \quad 27 \quad 18.0$ & 580 & $63 / 4 P A L$ & \\
\hline
\end{tabular}

The datid used in this sturly are from the stations shown in Figure 1. The solid line in this figure is a rereat circld path through Palisades, N.Y., and the station code identifying each of the stations corresponds to the three letter code assigned by the $O S C \& G S$. Readings of the phases which constitute the data were done from lors-period recordings having a natural period of 30 sec and 100 sec for the seismometer and galvanometer, respectively.

Figue 2 slows a graphical description of the phases which have undergone four reflections at the come-mantle boundary, denoted as 
$4(S C S)$, through the minor eircle path and recorded at $\$ C H$. Also in the same figure is shown a phase which travels through the major circle path and has been reflected three times at the core-mantle boundary, denoted as $3(S c S)^{-}$, and also recorded at the sume station.

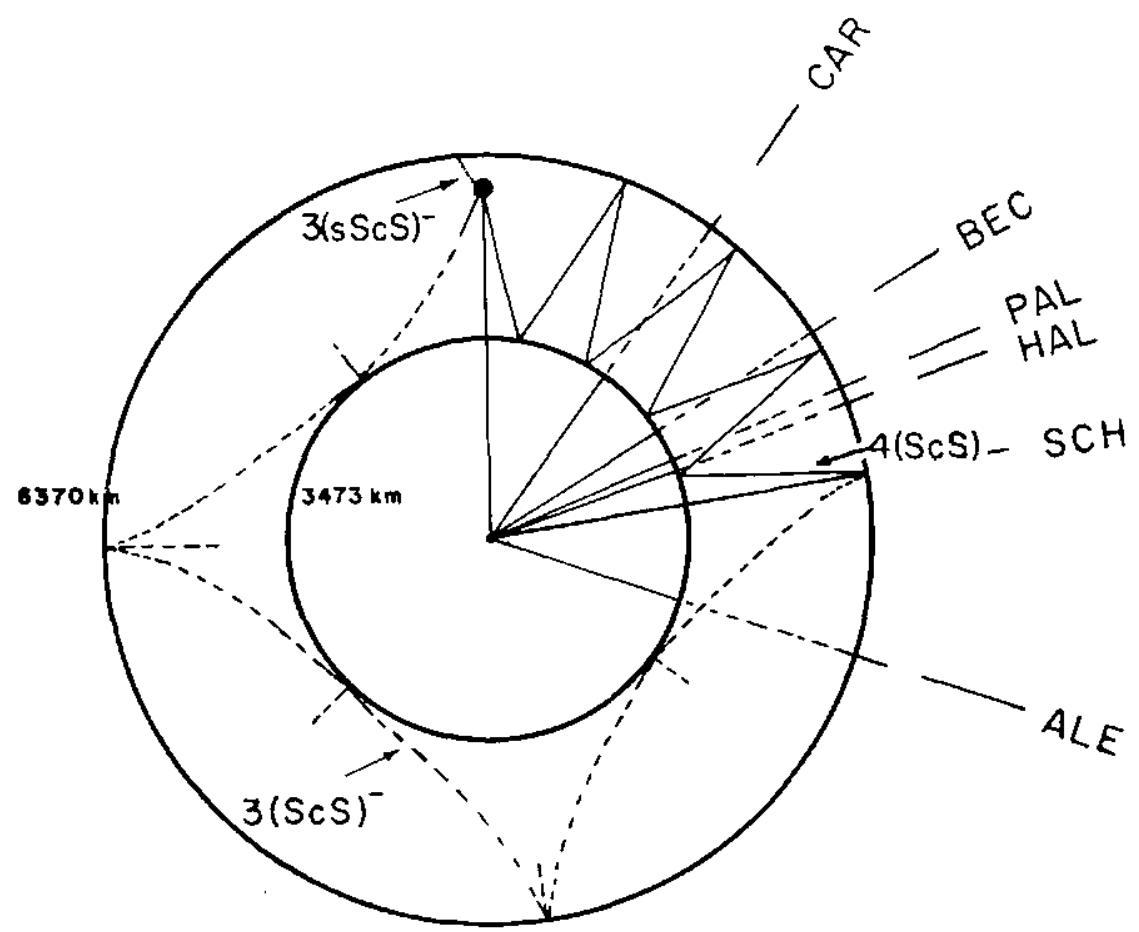

Fig. 2 - Graphical example of ray paths and notations used for the multiplyreflected phases which have traveled along the minor and major circle paths.

Figure 3 shows a tracing of the $E-W$ component seismogram at $C A R$, with an epicentral distance of $36.24^{\circ}$ and an azimuth from the station to the epicenter of $174.61^{\circ}$. The original recording was done on a recorder with a $30 \mathrm{~mm} / \mathrm{min}$. revolution satr. In this figure, the tracing has been reduced by a factor of four. The portion of this recording is between the arrival time of the $S$ phase and approximately a minute after the arrival time of the $4(S c S)$. On the original seismogram, the peak-to-peak amplitude of the $S e S$ phase is $357 \mathrm{~mm}$. The $n(S c S)$ and $n(s S c S)$ are indicated on the seismogram. The identification of the $n(S c S)$ series has been made certain by the arrival of its surface images on the recordings. 


\section{(SH)}

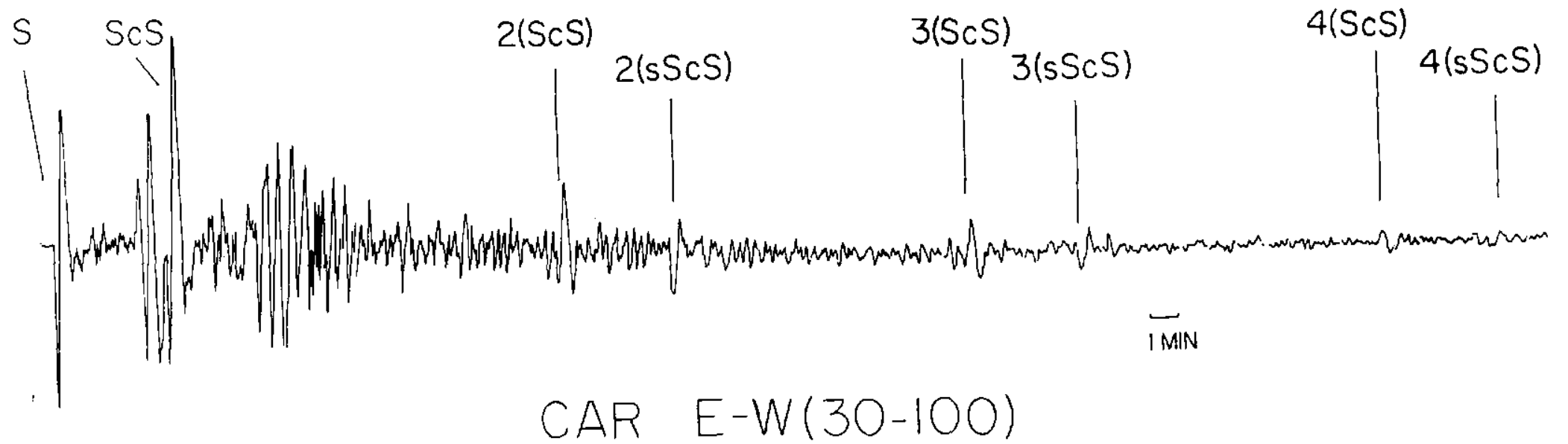

Fig. 3 - Seismogram from $C A R$, December 8, 1962, $E-W$ long-period component.

$(\mathrm{SH})$

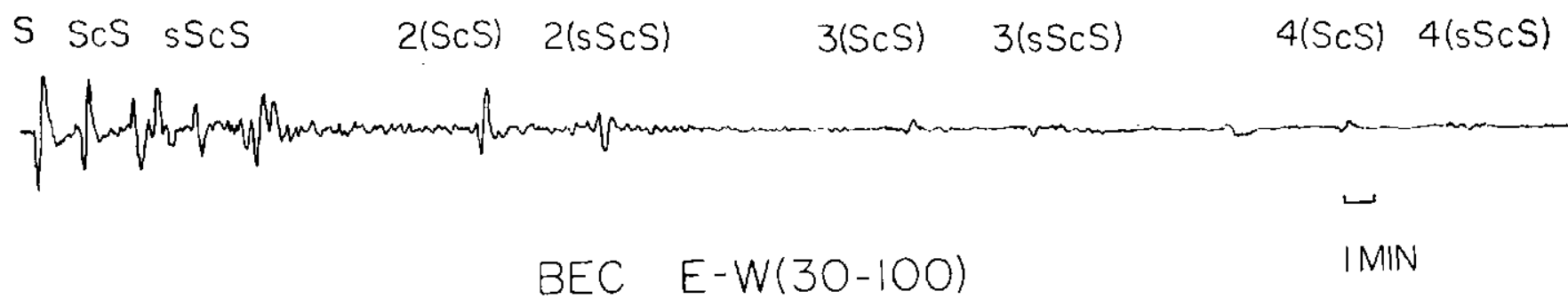

Fig. 4 - Seismogram from $B E C$, December 8, 1962, $E$-W long-period component. 


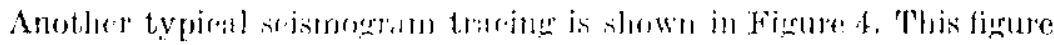

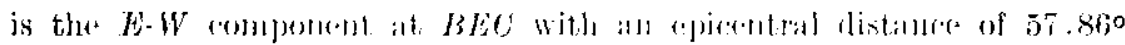

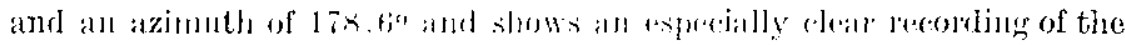

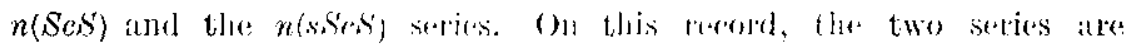

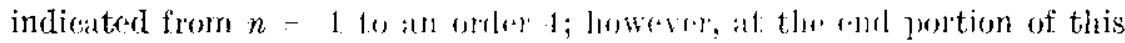

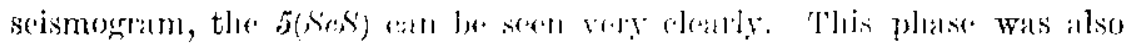

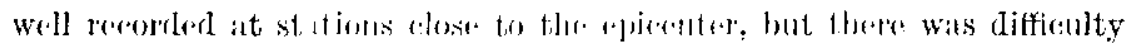

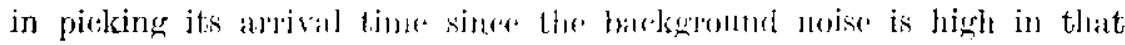

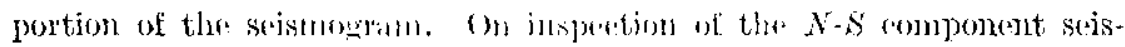
mogram, the horizontetly polarizerl shatr phases alde vely small in

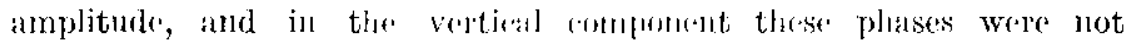
discerpuible.

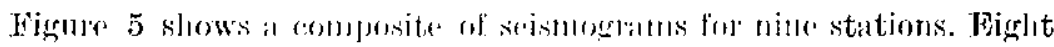

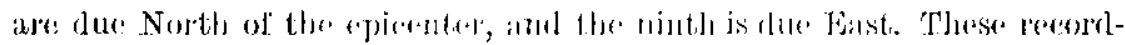

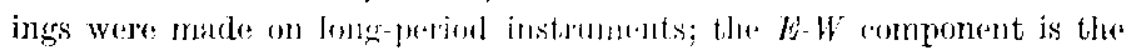

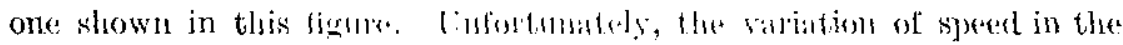
revolution of the rllom is rlifiegent lor semene of these stations; some have

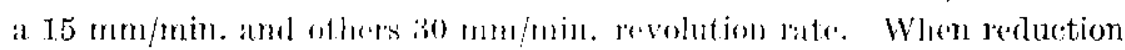

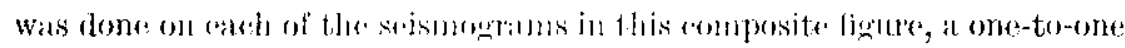

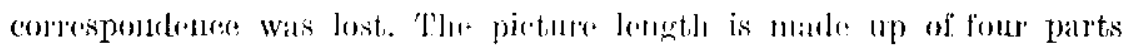

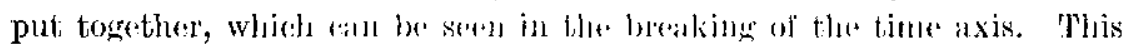
fact also has introrlurerl disterdion, and becallse of these distortions, no attempt is made to rataw a travel-time sarve which connect one phase with another for a sireng series. The $A N T, B A A$, and $A R E$

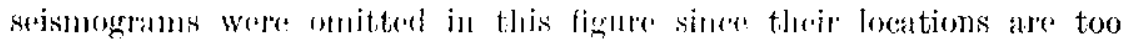

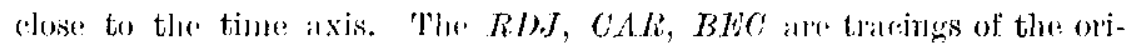
ginals, and the PAL, $I A L, S C H, V I O$, RES, and $A T E$ are pertuced pietures of the original sejomogram at theses stations. The time axis is in minutes, with an intrrval of 2 minutes, and the distance axis is in dergrees.

\section{Traveto-Time culzVes.}

The seismograms obtind from 38 of the $I G Y, U S C \& G S$, and the Ganadian stations were read (see Figure 1) and it total of 23 station reeords were used in the final gathering of the data which is used to construct the travel-time curves for the nultiply-leslecten phases. To interpret the phases on the recordings, the trivel times of impulsive phases were pieked, tathulated, and plotited. 'Thesse marlings ware done on all three 


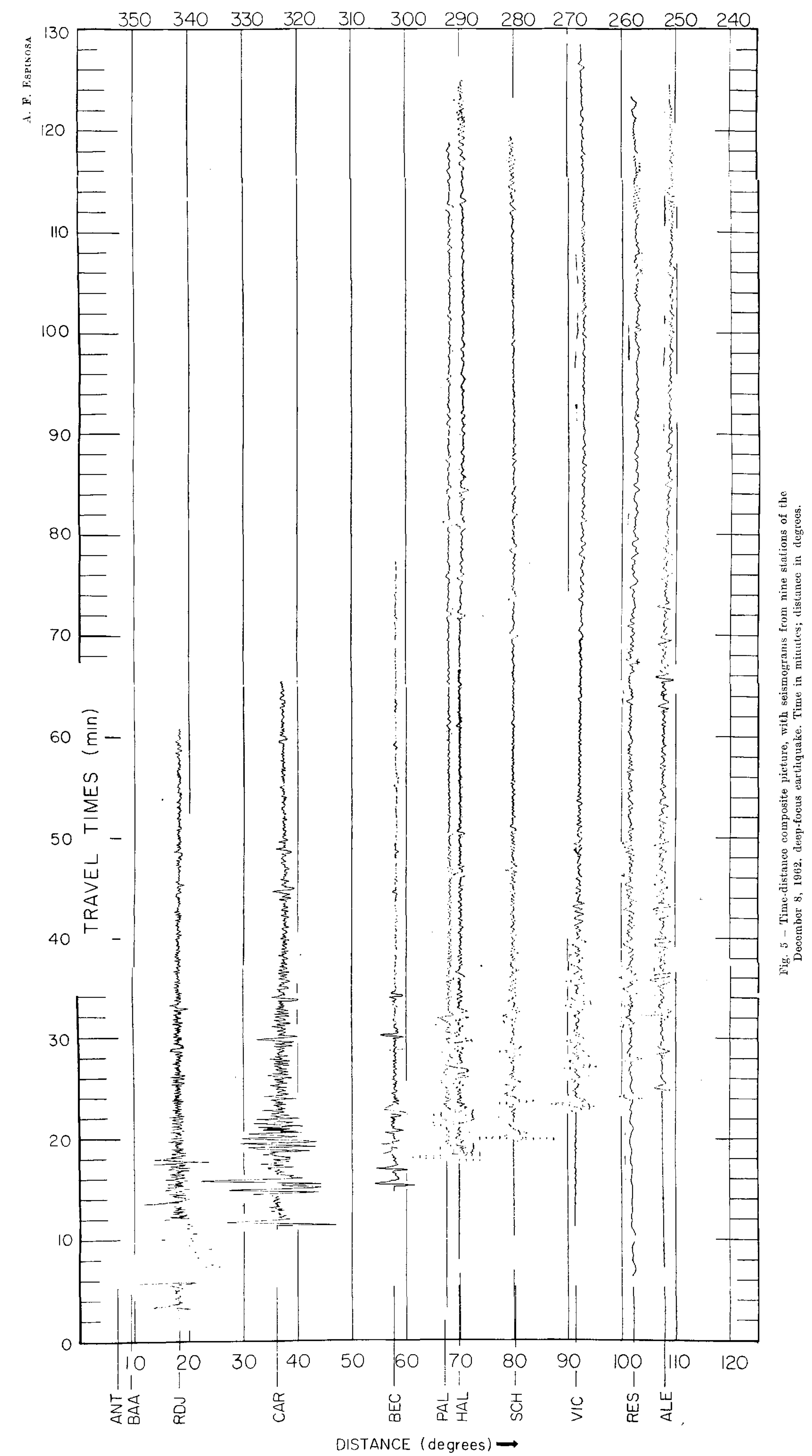




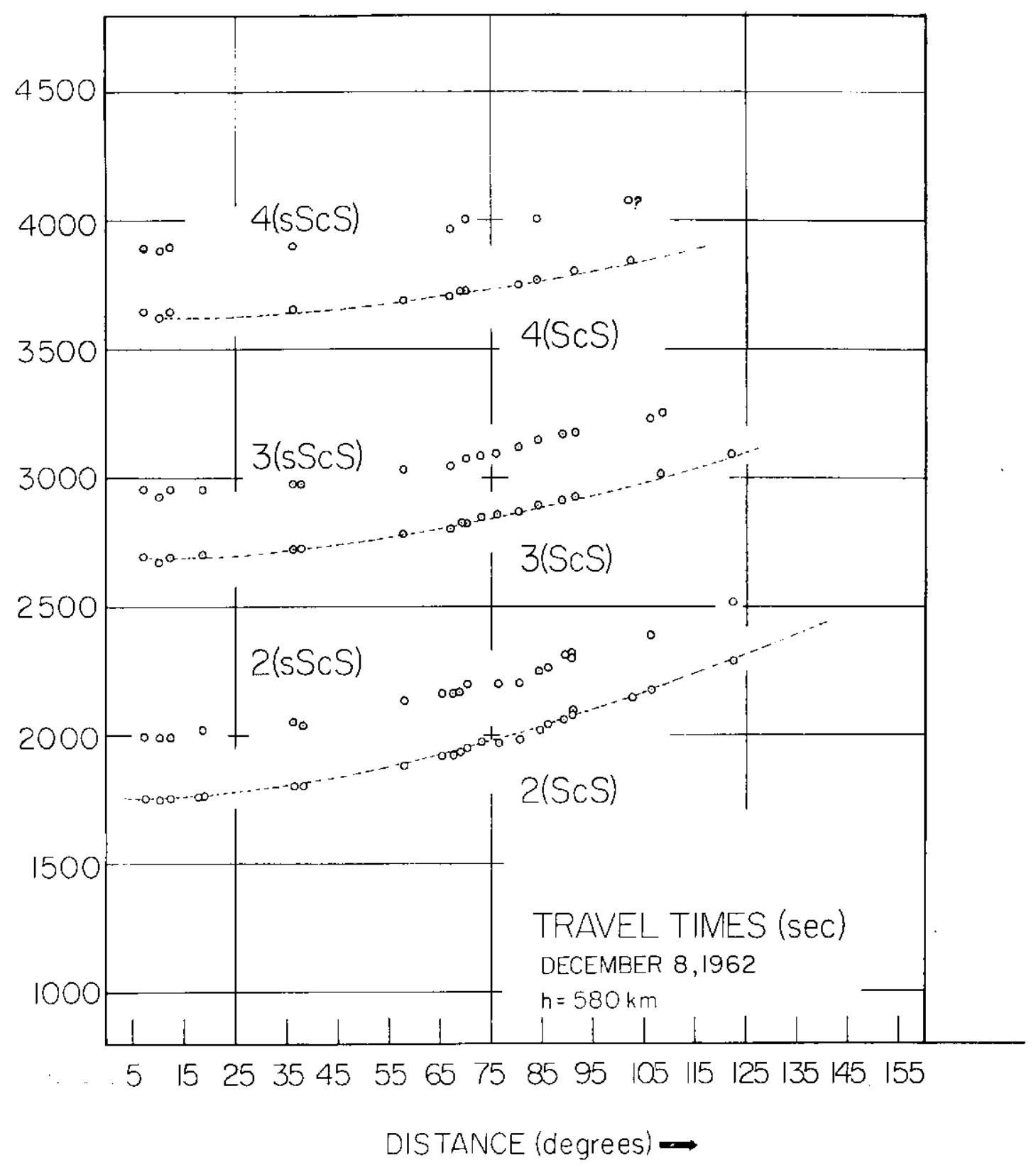

Fig. 6 - Observed travel times for the $n(S c S)$ and the $n(s S c S)$ series. Time in seconds; distance in degrees. 
components. After identification of the phases was certain, ellipticity corrections were applied to each of the readings. Figure 6 shows the travel times for the $n\left(S c S^{\prime}\right)$ and $n\left(s S c S^{\prime}\right)$ series obtained from the deep-

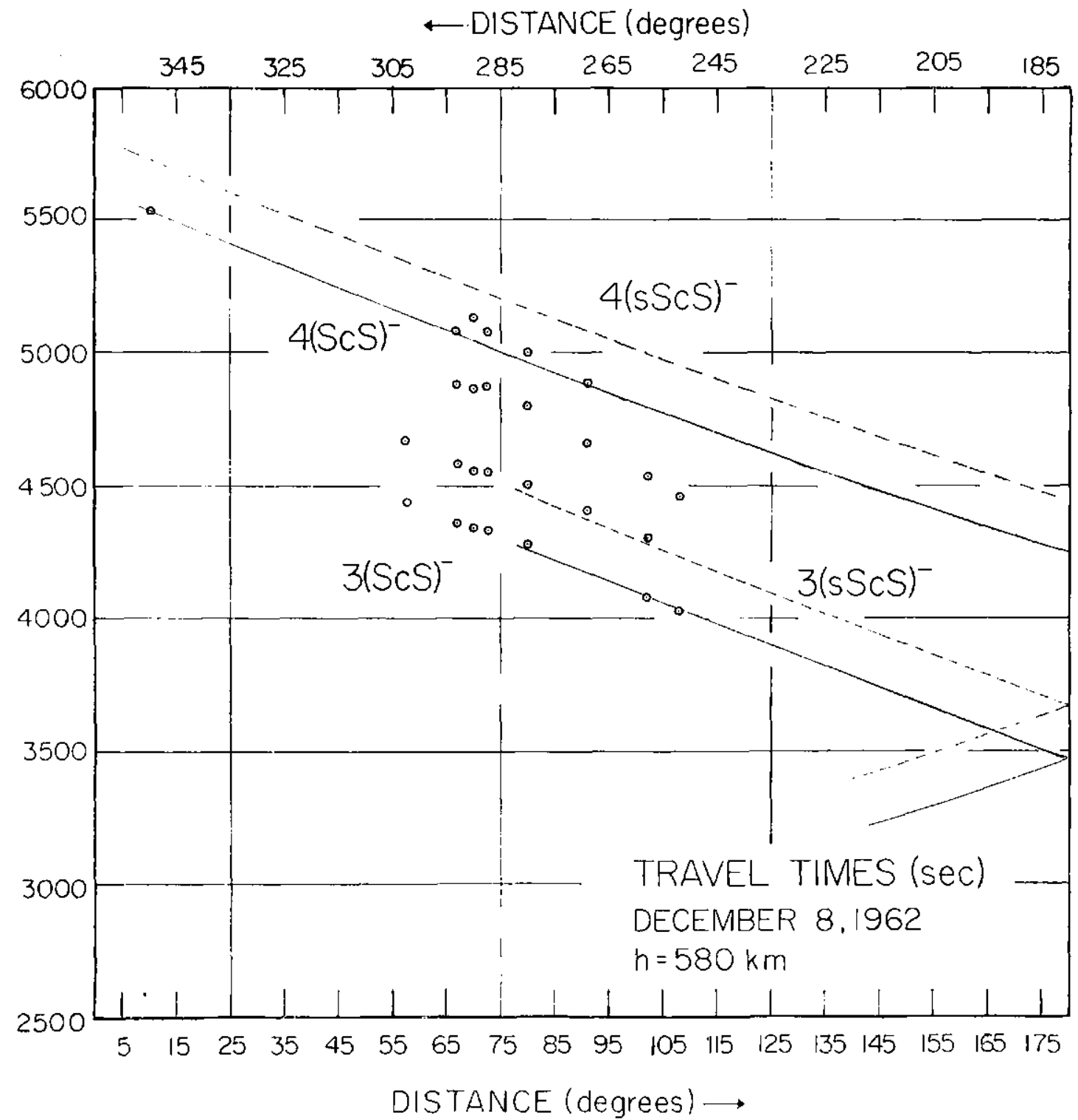

Fig. 7 - Observed travel times for the $3(S c S)^{-}$and $3(s S c S)$ - phases. Time in seconds; distance in degrees. 


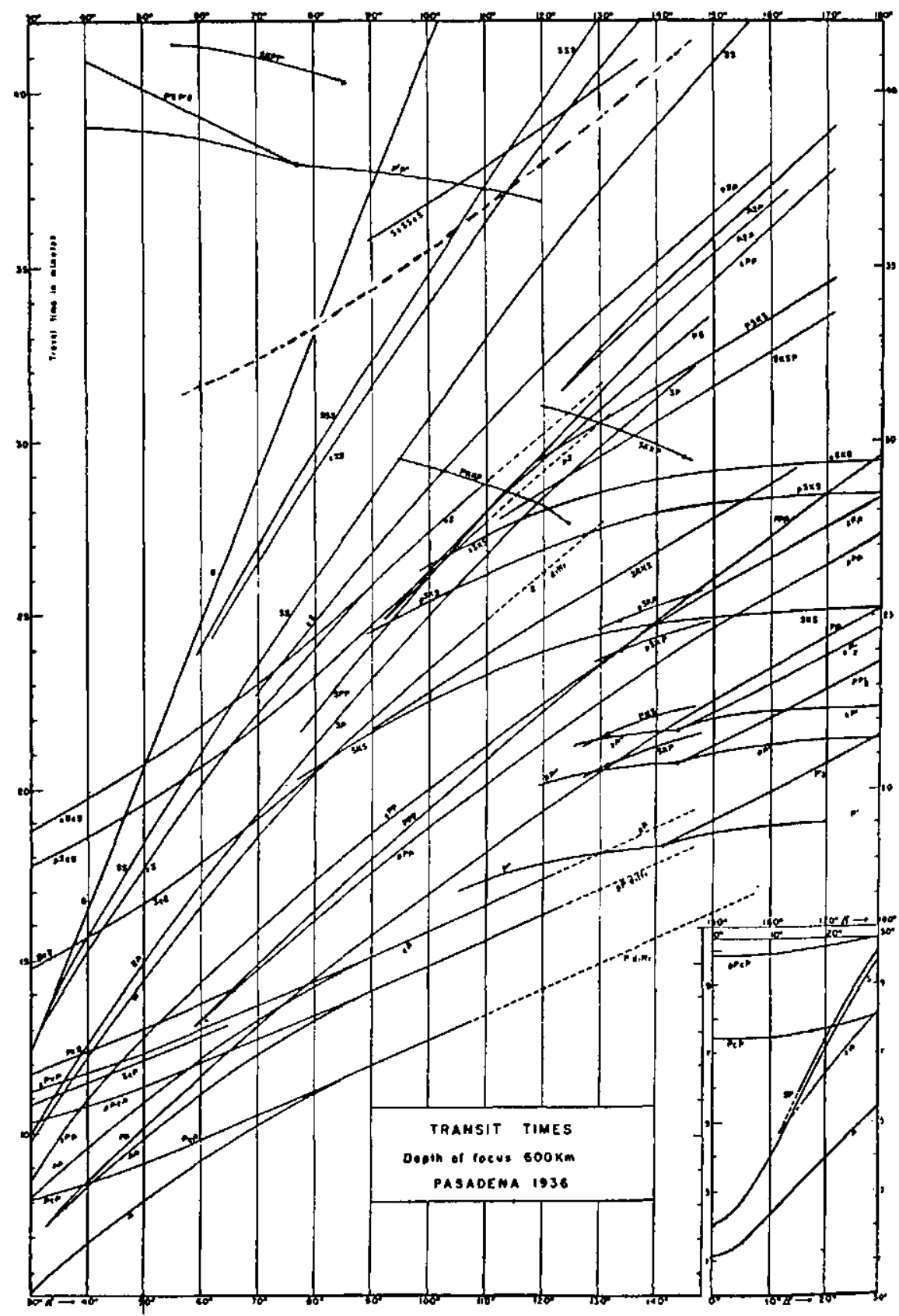

Fig. 8 - Travel-time curves (after Richter). 'The dash-line travel-time curvo corresponds to the correct curve for the $2(S c S)$ phase. 
focus earthquake of Decmber 8, 1962. Time is given in seconds and distance in degrees. The criterion used in the identification of the $n(S c S)$ series is that of the presence of its surface images on the recordings (see Figures 3, 4, and 5).

The dashed curves in this figure correspond to the travel times for $2(S c S), 3(S c S)$, and $4(S C S)$ for a depth of focus of $580 \mathrm{~km}$. Some of the observed points on these curves were checked against the Jeffreys and Bullen tables (1948), using the times of Ses for a surface foei and the corresponding depth allowaness. At first, Gutenberg and Richter travel-time rurves for $h=600 \mathrm{~km}$ we' used; however, the observed travel times from this eartholule aliepicentral distances of $90^{\circ}$ to approximately $125^{\circ}$ were allice thin the times given by their curves. In this figure, the $n(S C S)$ and thr $n(n S C S)$ series are plotted up to order $n=4$. The identifiention of order $n=5$ was possible in many of the records, bent the seatter of the latul radings was large'; henne, these readings were omitted. The reenty installed long-period instruments by the USC\&GS in south Ameria made Iossible the gathering of the data at close epicentral distances, and hence, the extension of the travel time observations of the $2(S C S)$ down to an epicentral distance of $r^{\circ}$.

In Figure 7 are shown the travel times of some of the plases which have arriver through the major arele jath. The solid lines rorrespond to the travel-tine curves for the $2(S C S)^{-}$, and the $\Psi(S e C)^{-}$, and the dashed lines to uheir corresponding sturlare intages. The observations of the "arlier arrivals in this figure lit those of the $3(S c s)$ - and the latter ones fit those of their surface image. Aftex the arrival times of the $3\left(s S c S^{3}\right)^{-}$, there are a number of obsarvations which rlo not fit the $4(S C S)$ - traveltime curve, and the litter arrivals seatter very much, so one cannot idertify, with artuinty, these phases as boing of the $4(S c S)$ - series. These phases in question are alealy recorderl on some of the seismograms (see Figure 5) with amplitudes larger than those phases which have arrived through the minot cirede patil.

Figure 8 shows the travel-time eurves given in Riehter's book, "Elementary Seismology", on page 68t, and on it a dashed traveltime curve has beern drawn which corresponds to the correct travel-time curve for the $2(S c S)$ phase obtuined in this study. The travel-time curve publisherl earlier by Gutrnberg and Riuhter (1937) for the same phase, for a depth of focus of $600 \mathrm{~km}$, should be redrawn as the dashed travel-time curve shown in Figures 6 and 8. 


\section{REFEREXCES}

BoLt B. A., The Revision of Earlhquake Epienters, Focal Depths and Origin Times Using a High-Speed Compuler. Geophrsical Joumal, Vol. 3, $433-440(1960)$.

Gutenberg B. and Richten C. F., Donnes Relatives a L'étude Des Tremblements de Terre a Foyer Profond. Publications du Bureau Central Séismologique International, Ser. $\Lambda$, Travaux Scientifiques, 15, 1.70 (1937).

Jefrreys H. and Bullex K. E., Seismological Tables. London, British Association (1948).

RrChter C. F., Elementary Seismology. Freeman \& Co., San Francisco (1958). 